\title{
Positive predictive value of Interferon-gamma release assay for incident active tuberculosis in HIV-infected persons
}

\author{
Susan Shin-Jung Lee*, Hsi-Hsun Lin, Hung-Chin Tsai, Yen-Yun Ni, Yao-Shen Chen, Chi-Tai Fang \\ From 17th International Symposium on HIV and Emerging Infectious Diseases (ISHEID) \\ Marseille, France. 23-25 May 2012
}

\section{Introduction}

Tuberculosis (TB) is the leading cause of death in HIV/ AIDS. The incidence of active TB is 30 times higher in HIV-infected persons. Treatment of latent TB infection (LTBI) is pivotal to the control of TB. We aim to determine the positive predictive value of an interferongamma release assay, QuantiFERON-TB GOLD test (QFT), for incident active TB in HIV-infected persons.

\section{Materials and methods}

This prospective, 5-year, cohort study enrolled HIVinfected adults without active TB. Demographic data, past exposure to TB and previous TB disease, HIV risk factors, CD4 counts, and HIV viral loads were recorded. QFT tests were done at entry. Cases of incident TB disease were ascertained by linking to our national $\mathrm{TB}$ database registry.

\section{Results}

We recruited 774 HIV-infected adults, with a mean age of 36.9 years, mostly men (96.8\%). HIV risk factors included intravenous drug user (67.2\%), men-who-havesex-with-men (24.2\%), and heterosexual (7.9\%). QFT was positive in $90(11.6 \%, 95 \% \mathrm{CI}$ : $9.5-14.1 \%)$ and indeterminate in $31(4.0 \%)$. On multivariate logistic regression analysis, significant risk factors for QFT positivity included older age, females, past TB disease and exposure to $\mathrm{TB}$.

Fifteen incident active TB cases (rate: 5.19/1000 person-years $95 \%$ CI:3.13-8.61) occurred during a mean follow up time of 3.73 person-years, with the majority (91.3\%) followed up for over 2 years. Incident active TB

\footnotetext{
* Correspondence: ssjlee@gmail.com

Kaohsiung Veterans General Hospital, Kaohsiung, Taiwan, Province of China
}

disease occurred in 5.6\% (5/90) of those with a positive QFT result, 3.2\% (1/31) indeterminate results, and 1.4\% with a negative QFT result $(\mathrm{p}=0.03)$. Hazard ratio for developing active TB was 3.10 (95\%CI:1.03-9.30, $\mathrm{p}=0.04$ ) for a positive QFT and $1.72(\mathrm{p}=0.60)$ for an indeterminate QFT result.

\section{Conclusions}

Our study demonstrated that QFT test predicted incident active TB disease in HIV-infected persons, with a hazard ratio of 3.10. QFT can be used for diagnosis of LTBI in HIV-infected persons, to allow targeted treatment in this high risk group.

Published: 25 May 2012

doi:10.1186/1742-4690-9-S1-P133

Cite this article as: Lee et al:: Positive predictive value of Interferongamma release assay for incident active tuberculosis in HIV-infected persons. Retrovirology 2012 9(Suppl 1):P133.

Submit your next manuscript to BioMed Central and take full advantage of:

- Convenient online submission

- Thorough peer review

- No space constraints or color figure charges

- Immediate publication on acceptance

- Inclusion in PubMed, CAS, Scopus and Google Scholar

- Research which is freely available for redistribution

Submit your manuscript at www.biomedcentral.com/submit 